\title{
7. The solidarity constitution in the EU: refugees and asylum as litmus test
}

\section{Joxerramon Bengoetxea}

\section{INTRODUCTION}

Solidarity is an important value for any community, and the EU Treaties aptly proclaim it. This evaluative commitment should deliver law and policies that enact solidarity in different areas, including that of Justice and Home Affairs. After this introductory section, section 2 of this chapter analyses solidarity as a value in the EU, going through the bonds and networks of solidarity to and between 'strangers', and how solidarity has been put to the test, since the entry into force of the Lisbon Treaty. Section 3 takes as a case study refugees seeking asylum in Europe and how European solidarity works (or fails), finding a stark contrast between the value of solidarity proclaimed by the Treaties and the practice of EU policy. In particular, it identifies a shift from a principle-based towards a more securitised approach in which the 'security' constitution is placed above the 'solidarity' constitution. Section 4 concludes and is a call to recover the spirit of solidarity in practice and policy design, reclaiming its constitutional status within the EU legal system.

\section{BONDS AND NETWORKS OF SOLIDARITY IN THE EU}

Europe is in a multidimensional and multitemporal process of constitutionalisation that ranges from juridical and political constitutions to sectoral ones, namely micro- and macro-economic, social and security constitutions. ${ }^{1}$ This chapter builds on Kaarlo Tuori's theory to suggest another dimension, namely the solidarity constitution, which very well fits his theory as the alter ego of the social constitution. When facing strangers, communities can adopt different approaches within a scale ranging from solidarity - that is, protection and

\footnotetext{
1 Kaarlo Tuori, 'The Many Constitutions of Europe' in Kaarlo Tuori and Suvi Sankari (eds), The Many Constitutions of Europe (Ashgate 2010).
} 
welcome - to security - that is, control and exclusion. Essential to European integration, solidarity is a matter of scale and degree. Within a community, it is a unilateral individual or collective response providing help, assistance or support to another person or group and driven by a feeling of empathy based on their real or perceived needs, and on the common good of the community. Solidarity applies not only within communities or peoples but also between them. It answers to the perception of need and the drive to provide support, and is based on cosmopolitan values like our shared human dignity, the higher common good in global justice and our shared environmental destiny.

Solidarity gives rise to a moral duty of support, stronger than generosity but weaker than the obligation involved in family bonds, love or close friendship. It extends to people we do not know, to strangers. Their needs, and our empathic sentiment towards them, trigger our support to the extent that we consider them as part of our larger community. Even though a legal right of the needy to solidarity or a correlative legal duty of solidarity by the well-off are contested claims in the absence of specific engagement by the parties involved, it nevertheless remains arguable that mutual empathy and support constitute bonds of implied reciprocity and commonality of fate generating social trust. ${ }^{2}$

The EU is, thus, a system of solidarity with, and between, strangers. Historically, nation-states created national systems of solidarity through basic education, national broadcasting media, military conscription, public health provision, social security and other social services, with language, ethnicity and religion being additional community-building factors related to solidarity. These factors mix in different ways, sometimes forming regional variations. ${ }^{3}$ National systems of solidarity benefited the nationals of the state, excluding non-nationals. Foreigners were strangers, increasingly so, as the nation-state was becoming a bureaucratic welfare state. International law at best enabled the free movement of goods through commercial agreements. A single customs territory was the first step in the unification of Germany in the second half of the nineteenth century and, when suggested for Western Europe after the Second World War, it was considered a revolutionary novelty in international cooperation. It is thus easy to understand how insightful Jean Monnet

2 For a summary of the history and centrality of 'solidarity' in sociological theory see Reza Banakar, 'Law, Love and Responsibility: A Note on Solidarity in EU Law' in Reza Banakar, Karl Dahlstrand and Lotti Ryberg Welander (eds), Festskrift till Håkan Hydén (Juristförlaget i Lund 2018). A more detailed analysis is in Eleni Karageorgiou, Rethinking Solidarity in European Asylum Law (PhD thesis, Lund 2018), ch 7.

3 See for instance the classification of the different regimes made by Gøsta Esping-Andersen, The Three Worlds of Welfare Capitalism (Princeton University Press 1990). 
was in his vision of uniting persons rather than coalescing states, ${ }^{4}$ and how ambitious the European Communities vision was in aiming to achieve 'an ever closer union among the peoples of Europe', not among states. Member States were not seen as an end in themselves, but rather as the technical instrument of institutional and regulatory integration of citizens in a supranational sphere.

Integration was to be realised by creating first a common market and later a single market, going far beyond known systems of free trade and customs unions (free movement of goods) to embrace the free movement of persons (workers, self-employed and non-active persons alike, including the freedom of movement for services and the freedom of establishment). This is where peoples and citizens get directly involved. Free movement of persons included the right to move and reside within the territory of any of the Member States, which thus became the territory of the Union, also as regards persons. This new common territory involved eliminating border controls, something that was not perfectly accomplished throughout the Union. ${ }^{5}$ Free movement of persons started with migrant workers and self-employed professionals, but eventually extended to all citizens. With the introduction of Union citizenship Member States gradually lose full dominion over populations, no longer deciding who can or cannot enter or leave, or who can stay within their borders. ${ }^{6}$

At least symbolically, those who, until the creation of the EU, were étrangers, or at best economic factors of production (employed workers, self-employed professionals or members of their families), suddenly became fellow citizens in a common polity - the EU - and for many essential purposes Member States could no longer treat them as strangers. ${ }^{7}$ Part Two of the TEU is aptly entitled 'non-discrimination and citizenship of the Union', and prohibits discrimination on the grounds of nationality. Solidarity is thus materialised through free movement rights, through the elimination of barriers that hinder free movement in the territory of the Union, and through the prohibition of any form of discrimination on the basis of nationality. In other words, as regards citizens of the Union, the Treaty allows no distinction between national and

\footnotetext{
4 'Nous ne coalisons pas des Etats, nous unissons des hommes.' Speech given at the National Press Club, Washington DC, 30 April 1952.

5 The UK (and Ireland) did not participate in the Schengen agreement, but Norway, Iceland and Switzerland did. More importantly, the application of Schengen is often suspended by some Member States, invoking the emergency clause. Borders and frontiers are reinstated with the 'state of exception', which reaffirms national control as witnessed currently with regard to the Covid-19 pandemic: see the Introduction to the present volume.

6 None of the three dimensions of citizenship - civil, political and social - has really materialised since the citizenship of the Union was introduced in the Maastricht Treaty, but free movement has. See Antonios Kouroutakis, ch 6 in this volume.

7 Samuli Hurri, The Birth of the European Individual (Routledge 2014).
} 
stranger. With the first citizenship case decided by the ECJ, ${ }^{8}$ a new form of transnational solidarity between citizens of the EU was, in fact, affirmed.

With Brexit, discrimination on grounds of nationality is back and an alternative to the single market, a panacea to keep nationals together by excluding outsiders, building on visions of a free, more caring, inward-looking welfare state - a protection of 'us' from the threat of 'others' - is promised. ${ }^{9}$ Fraternité shrinks to fellow nationals. Post-Brexit, the EU has the chance to demonstrate that it takes the solidarity constitution seriously, also towards 'strangers'. The refugee question, discussed below, provides a good testing ground to measure this commitment.

\subsection{Solidarity as 'Federalism from Below'}

European integration is thus based on bonds of solidarity; it 'connects peoples' in networks of trust. The institutionalisation and concretisation of mutual solidarity is the gist of European integration - its ultimate telos. But there is a growing gap between the grandiosity of its values (Article 2 TEU) and missions (Article 3 TEU), on the one hand, and the mediocrity of its tools and rigidity of its decision-making, on the other. As Monar has argued, 'solidarity in the EU is still more of an instrument to address certain functional challenges rather than a community value and constitutional principle'. ${ }^{10}$ Member States should be instruments, not ends: they coalesce, pace Monnet, so that peoples and citizens can unite, ever more closely, in networks of factual solidarity that make war unthinkable. ${ }^{11}$ This is, in essence, the ethos of the Schuman declaration, adopted in 1950. European integration should not pivot on the states

8 Case C-85/96 María Martinez Sala v Freistaat Bayern, ECLI:EU:C:1998:217, confirmed in the ratio in Case C-184/99 Rudy Grzelczyck v Centre public d'aide sociale d'Ottignies-Louvain-la-Neuve, ECLI:EU:C:2001:458.

9 Juhn Judis, The Populist Explosion: How the Great Recession Transformed American and European Politics (Columbia Global Reports 2016); see also Juhn Judis, 'Us v Them: the birth of populism' (The Guardian, 13 October 2016).

10 Jörg Monar, 'The AFSJ Two Decades after Tampere: Institutional Balance, Relation to Citizens and Solidarity' in Sergio Carrera, Deirdre Curtin and Andrew Geddes (eds), 20 Year Anniversary of the Tampere Programme: Europeanisation Dynamics of the EU Area of Freedom, Security and Justice (EUI 2020). But see Daniel Thym and Evangelia Tsourdi, 'Searching for solidarity in the EU asylum and border policies: Constitutional and operational dimensions' (2017) 24(5) Maastricht Journal of European and Comparative Law 605, who hold that solidarity in EU law has constitutional significance and 'can be compared to a growing tree: it develops different branches that all rest on a common trunk and continue to relate to each other in balancing the overall stability of the tree when it gains height and volumen'.

11 Ernst B. Haas, The Uniting of Europe (Notre Dame 2004), Alec Stone Sweet and Wayne Sandholtz (eds), European Integration and Supranational Governance 
and their national governments, central as they are, but rather on citizens and peoples.

Uniting persons and peoples in any polity is an ambitious endeavour which involves the creation of public and institutional spaces, allowing for the development of a shared cultural and political identity, and the arrangement of solidarity, combining distributive and redistributive institutions. This foundational aspiration of European integration is an aim or finalité of the EU, a complex federal polity aiming at 'an ever closer union among the peoples of Europe' (Preamble and Article 1 TEU) where distributive and redistributive functions and institutions coordinate at all levels. Connecting peoples involves not only devising spaces of shared government where peoples decide jointly on matters of common concern, but also respecting forms of self-determination where those peoples or demoi govern themselves democratically. ${ }^{12}$

This project of (federal) solidarity, coalescing states, integrating peoples and uniting citizens in common European institutions is under attack by zealot nationalists who advocate returning to 'nation first' forms of solidarity. At one end, defenders of the nation-state pushback call for greater integration by reverting to populism. At the other end, defenders of the Euro-state see the Union as an irreversible Hegelian historical necessity, an inevitable outcome of a hegemonic, cosmopolitan and liberal project. Somewhere in the middle, European federalists insist that membership of the Union is precisely the result of a free choice of the people, respecting solidarity, subsidiarity and self-government. As Banakar argued, 'the assumption that the Member States can be united by solidarity at the transnational level, while their citizens remain divided at the national level and sceptical of the EU institutions' legitimacy, is a sociological misnomer'. ${ }^{13}$ Instead, bottom-up European federalism or 'federalism from below' respects the original sovereignty of the peoples that freely come together in a spirit of solidarity and cooperation, jointly setting up public institutions to govern common issues.

\subsection{Solidarity in the EU Treaties}

The Treaties take a high-scale approach to solidarity. On the international scene, 'Member States shall show mutual solidarity' (Article 32 TEU) and since solidarity 'binds Europe and the overseas countries', the Member States desire to ensure the development of their prosperity, in accordance with the

(OUP 1998) and A. Stone Sweet, Wayne Sandholtz and Neil Fligstein (eds), The Institutionalization of Europe (OUP 2001).

12 Zygmunt Bauman, A Chronicle of Crisis 2011-2016 (Social Europe 2017) ch 22.

13 Banakar (n 2). 
principles of the Charter of the United Nations (Preamble TFEU). Likewise, Articles 3 and 21 TEU proclaim equality and 'solidarity and mutual respect among peoples'. They add an interesting dimension - time - where Article 3 TEU mentions 'solidarity between generations' ${ }^{14}$ sketching some form of intergenerational solidarity. International solidarity is a matter of degree: as a minimum, as in Article $31 \mathrm{TEU}$, it implies that a Member State 'refrain from any action likely to conflict with or impede Union action based on' a Council decision requiring operational action of the Union in external affairs, and it requires the other Member States to respect its position.

Solidarity reaches more intense degrees internally, within the Union. In the Area of Freedom, Security and Justice (AFSJ), Article 67(2) TFEU prescribes a 'common policy on asylum, immigration and external border control, based on solidarity between Member States, which is fair towards third-country nationals'. Article 122 TFEU also contemplates an enhanced 'spirit of solidarity', requiring assistance with energy supply where a Member State is facing severe difficulties in the supply of certain products or is seriously threatened with severe difficulties caused by natural disasters or exceptional occurrences beyond its control. In such cases the Council, on a proposal from the Commission, may grant, under certain conditions, Union financial assistance and inform the Parliament.

Most significantly, the Lisbon Treaties have enshrined a solidarity clause in Title VII of Part Five (External Action). Article 222 TFEU provides that 'the Union and its Member States shall act jointly in a spirit of solidarity if a Member State is the object of a terrorist attack or the victim of a natural or man-made disaster', mobilising 'all the instruments at its disposal, including the military resources made available by the Member States' upon the request of the Member States' political authorities. This will put to test the spirit of solidarity connecting peoples. External action relating to the Covid-19 pandemic, treated by the World Health Organisation as a 'natural or man-made disaster', would require the Union and its Member States to provide financial assistance (Article 122 TFEU) and mobilise all available instruments (Article 222 TFEU) where necessary. The Recovery Plan for Europe, coupled with NextGenerationEU, arguably does precisely that. ${ }^{15}$

In light of the above, solidarity starts as a value (Article 2 TEU); continues as a principle informing the policies on border checks, asylum and immigration, and their implementation (Article $80 \mathrm{TFEU}$ ); moves to a conditional

14 Other dimensions are the spatial-geographical (between states), the personal (refugee protection) or the structural-institutional (institutions of solidarity such as redistributive mechanisms or social security).

15 Next Generation EU https://ec.europa.eu/info/strategy/recovery-plan-europe_en accessed 31 March 2021. 
permission (Article 122 TFEU); and culminates as a full-blown obligation (Article 222 TFEU and in Declaration 37 on Article 222 TFEU). As a practical reason - value, preference or spirit - solidarity feeds into the law in the form of (i) a legal value or general principle of law, aiding legal construction and systemic interpretation, generating legal standards and directly informing norms; or (ii) concrete legal rules, as in Articles 78(3) and 80 TFEU, providing for fair sharing of responsibilities relating to refugee protection; ${ }^{16}$ or Article 222 TFEU and Declaration 37, which turn solidarity into a legal obligation, Member States choosing the means to comply.

Solidarity is not only a matter of degree but also a matter of scale, a question of elevating the geographical sphere of community, since it obtains in the different levels and spheres from the social group or community, through the public institutions and the multiple administrative levels within states, all the way to the international sphere. Being between national and international spheres, European integration adds something qualitatively new to state-national solidarity, the dimension of scale and variable geometry. But as a cosmopolitan project based on shared humanity, European solidarity should not stop at the frontiers of Europe to create an enclosure, a sort of Festung Europa. The 'tsunami' of crisis waves affecting Europe ${ }^{17}$ throughout the twenty-first century has been testing the EU's solidarity at all levels. In the following paragraphs, the analysis will focus on the so-called 2015 European refugee crisis.

\section{THE STRUGGLE FOR SOLIDARITY IN THE CASE OF REFUGEES}

The elimination of internal frontiers and the creation of a new institution of EU law, citizenship of the Union, came with the strengthening of external borders and with a new category, the non-EU citizen, that is, third-country nationals or stateless persons. For them, entering the territory of the EU - crossing its external frontiers - became increasingly harder, and subject to strict controls. The Schengen agreement on the gradual abolition of checks at common

16 Pursuant to Article 80 TFEU, the principle of solidarity can deliver concrete legal and policy measures. In this sense solidarity is more than a guide to interpretation; it is a source of regulation and a ground for constitutional review. It has normative implications, at a minimum, delegating power to Member States' governments and EU institutions to reach compromises and make rules aiming at a fair distribution of asylum-related responsibilities: Karageorgiou (n 2) 234-5.

17 For instance, the attacks of 11 September 2001 and jihad terrorism; a failed constitutional treaty; the financial (sub-prime) crisis; economic and social crises; refugee and humanitarian crises; populism; the Ukraine issues; Brexit; the Covid-19 pandemic. 
borders in the mid-1980s and the creation of the EU in 1992 coincided with the re-emergence of discourses about 'fortress Europe', referring to its immigration policy. ${ }^{18}$

Inside the EU, solidarity was to apply to all persons, starting with EU citizens. Since the EC Treaty reforms signed in Amsterdam (1997) and the Tampere action programme on the AFSJ (1999), ${ }^{19}$ the need to extend this system of solidarity to a special group of non-citizens, that is, refugees and asylum seekers, was also contemplated as a political necessity. This was formally embodied in the Dublin Convention and Regulations, which make up an embryonic Common European Asylum System - a not very systematised ${ }^{20}$ set of regulations, directives and decisions that develops, at EU level, the cornerstone of the international legal regime for the protection of refugees, that is, the 1951 United Nations Convention Relating to the Status of Refugees (also known as Geneva Convention). ${ }^{21}$ Although the EU is not a contracting party to the Geneva Convention, its Member States are, and the TFEU (Article 78), the EU Charter of Fundamental Rights (hereinafter the Charter, Article 18) and secondary EU law require the EU to observe it. This system seeks to ensure full respect for human dignity and ensure asylum applicants' and their accompanying family members' rights when entering the EU territory. Member States retain competence on asylum, implementing the common EU rules at the national level.

\subsection{From Refugees to Suspect Migrants}

Refugees deserve a special 'solidarity' which takes the form of international protection because they are persecuted in their countries of origin. This derives

18 As Agustín José Menéndez and Espen D.H. Olsen argue in Challenging European Citizenship: Ideas and Realities in Contrast (Palgrave Macmillan 2020), at 7, '[w] hat sets the tone of European policy is not the opening towards third country nationals, but the emergence of a migration policy that discriminates on the basis of the "economic value" that migrants are reputed to contribute to the European Union'.

19 See Carrera et al (n 10).

20 Vincent Chetail, 'The Common European Asylum System: Bric-à-brac or System?' in Vincent Chetail, Philippe De Bruycker and Francesco Maiani (eds), Reforming the Common European Asylum System: The New European Refugee Law (Brill 2016).

${ }^{21}$ UN Convention Relating to the Status of Refugees 1951 (189 UNTS 137). The CJEU, in Joined Cases C-391/16, C-77/17 and C-78/17 M and others, $X$ and $X \mathrm{~V}$ Commissaire général aux réfugiés et aux apatrides ECLI:EU:C:2019:403, recalled that the Common European Asylum System is based on the full and inclusive application of the Geneva Convention and its New York Protocol, and on the guarantee that nobody will be sent back to a place where they again risk being persecuted (para 80). 
from the values that the EU proclaims in Article 2 TEU - 'human dignity, liberty, equality, human rights, tolerance, solidarity, peace, equality between men and women' - which call for an open society, plural, multicultural and democratic, where 'strangers' share a community and live together. ${ }^{22}$ This common vision enhances social trust and channels the Union towards the common good.

Until 2015 it seemed that the 'extension' of solidarity to refugees was acquis. ${ }^{23}$ That refugees fleeing persecution should move freely to seek asylum was once considered fair and legitimate. The persecuted refugee of the Geneva Convention was grafted into the European Union through the Qualification Directive. ${ }^{24}$ Refugees, protected by the principle of non-refoulement, ${ }^{25}$ would be refugiés sans frontieres in the EU, almost like citizens of the Union and enjoying most of the benefits of the AFSJ. The issue of refugees has been framed on paper as a question of inclusion and solidarity bonds, but the dominant frame in current practice is exclusion, stopping refugees before they reach the external borders of the EU and preventing the inflow of irregular (economic) migrants altogether.

With the war in Syria in 2015, some Member States refused this extension of solidarity to refugees who do not share 'Christian' values ${ }^{26}$ or insisted on stopping migrants 'swarming' into their territory. Claims to take back control of the borders, to suspend the Schengen rules and to restrict residence rights of

22 Zenon Bankowski, Living Lawfully: Love in Law and Love in Love (Springer 2001); also Banakar (n 2).

23 The Geneva Convention turned refugees into quasi-citizens, providing freedom to practise their religion and freedom as regards the religious education of their children (Art 4), free access to the courts of law (Art 16(1)) and elementary education (Art 22(1)), among other rights.

24 Directive 2011/95/EU of the European Parliament and of the Council of 13 December 2011 on standards for the qualification of third-country nationals or stateless persons as beneficiaries of international protection, for a uniform status for refugees or for persons eligible for subsidiary protection, and for the content of the protection granted (recast) [2011] OJ L337/9 (Qualification Directive).

25 Geneva Convention (Article 33) imposes on contracting states the obligation of non-refoulement: no expulsion or return of asylum seekers to the frontiers of territories where their life or freedom would be threatened on account of race, religion, nationality, membership of a particular social group or political opinion, unless there are reasonable grounds for regarding the refugee as a danger to the security of the country or to the community of that country.

26 The ethnic homogeneity argument was put forward by Poland and rejected in Cases C-643/15 and C-647/15 Slovak Republic and Hungary $v$ Council, ECLI:EU:C: 2017:631, paras 301 and 305. Contra, the Geneva Convention (Article 3) prescribes that Contracting States shall apply the Geneva Convention to refugees 'without discrimination as to race, religion or country of origin'. 
EU citizens and third-country nationals are abundant. ${ }^{27}$ In the EU, as a whole, the solidarity constitution is being outweighed by the security constitution. The special regime for protecting refugees is giving way to restrictive interpretations of the law, diluting refugee status into migrant status. Refugees, conflated with irregular migrants, are seen as a problem and a threat. Anti-refugee discourse and populist nationalism, as discussed earlier, are relevant here. Outright confrontation by some Member States, and right-wing and xenophobic narratives, have all created a dangerous mix where refugees are constructed as dangerous, instead of as persons 'in danger' and in need of solidarity. Above all, they are constructed as generating an unsustainable cost to national economies. On the opposite end, many European citizens are keen to express solidarity with the refugees and offer as volunteers to go to their rescue, sometimes facing legal charges in the Member States for favouring illegal migration. ${ }^{28}$ Thus, the issue of refugee protection not only confronts Member States, but has also divided and polarised societies in favour and against. Idealising refugees as innocent and passive victims, on the one hand, and stigmatising them as dangerous criminals, on the other, are two extreme clichés. ${ }^{29}$

\subsection{Refugees and European Solidarity in Crisis}

Until the second decade of the twenty-first century the system seemed to work sufficiently well, with ups and downs, ${ }^{30}$ but without any major crisis. From 2013 asylum applications in the EU started to increase, peaking in $2015 .{ }^{31}$ The Dublin system, which allocates asylum applicants among the EU Member States, ${ }^{32}$ collapsed, and Germany decided to deviate from its regular imple-

27 Anti-immigrant political parties and some national governments systematically call for an end to free movement, and the Covid-19 pandemic has provided an easy pretext to close borders: see the Introduction to this volume.

28 Some of the many instances in the EU are Mussie Zerai, Helena Maleno, Manuel Blanco and José Enrique Rodríguez: see Daniel Mendez, 'Cuando salvar vidas te puede llevar a la cárcel', in XL Semanal 27-02-2018 www.xlsemanal.com/actualidad/ 20180227/voluntarios-salvan-vidas-acusados-de-inmigracion-ilegal.html accessed 31 March 2021.

29. $M$ and others, $X$ and $X$ (n 21).

30 ECtHR case M.S.S. v Belgium and Greece [Grand Chamber], Application No. 30696/09, [2011] ECHR. The case is about Belgian transfers under the Dublin II Regulation to Greece, where reception conditions and asylum procedures were in breach of ECHR Article 13 in conjunction with Article 3.

31 Raluca Bejan, 'Why some EU countries are struggling to relocate migrants' (The Conversation 1 December 2019).

32 Regulation (EU) No 604/2013 of the European Parliament and of the Council of 26 June 2013 establishing the criteria and mechanisms for determining the Member State responsible for examining an application for international protection lodged in 
mentation in order to assist Greece and Italy with the large number of asylum applications. ${ }^{33}$ After political pressure, Germany subsequently decided to close its border with Austria to stop the inflow of refugees and asylum seekers, triggering a domino effect southwards to the Balkans. Hungary, as well as southern countries located at EU external borders, were particularly affected by these decisions, as many refugees were 'trapped' there after Germany and Austria closed their borders. ${ }^{34}$ Western powers are largely responsible for the unsuccessful management of the 'Arab Spring' (in countries such as Egypt and Libya) and of the Syrian war, the causes of civilians' flight to safer Europe. The EU's responsibility in the poor geopolitical and diplomatic management of its eastern and southern neighbourhoods seldom emerges in political debates or in EU policy documents, but it is a necessary explanation for this refugee crisis.

In view of this situation, the EU decided to relocate 160,000 asylum applicants to the least affected EU Member States over 2016 and 2017 on the basis of criteria such as size of GDP, population, unemployment rate and past record of asylum applications. ${ }^{35}$ This temporary emergency relocation mechanism, adopted in accordance with Article 78(3) TFEU, has proved divisive and inefficient. Some Member States preferred resettlement directly from countries neighbouring Syria, while others claimed that the relocation scheme should have been voluntary instead of an obligatory mechanism, which they perceive as a violation of their sovereignty. In particular, Decision 2015/1601 establishing provisional measures in the area of international protection for the benefit of Italy and Greece ${ }^{36}$ was challenged, unsuccessfully, by Hungary and Slovakia, supported by Poland. The Court of Justice of the EU declared

one of the Member States by a third-country national or a stateless person [2013] OJ L180/31 (Dublin III Regulation).

33 Article 17 Dublin III. Chancellor Merkel defended her Willkommenspolitik, while civil society in the EU organised reception and opened spaces for the migrants to regain the "personal identity they had been forcibly denied throughout their journey, or had lost in the tangles of depersonalising administrative procedures': see Alessandro Mazzola and Antoine Roblain, 'How do asylum seekers view Belgium's emergency system?' (The Conversation, 13 October 2019).

34 A similar situation was reported five years later, in February 2021, in Una-Sana, on the Bosnian-Croatian border, where 3000 migrants were trapped after being forcibly and brutally returned by Croatian police. See Border Violence Monitoring Network, www.borderviolence.eu/reconstructing-a-violent-pushback-of-asylum-seekers-from -croatia-to-bosnia-bvmn-border-investigations/ accessed 31 March 2021.

35 Council Decisions (EU) 2015/1503 and (EU) 2015/1601 of 22 September 2015 establishing provisional measures in the area of international protection for the benefit of Italy and Greece [2015] OJ L248/80.

36 Council Decision (EU) 2015/1601 of 22 September 2015 establishing provisional measures in the area of international protection for the benefit of Italy and Greece [2015] OJ L248/80. 
the relocation decisions lawful. ${ }^{37}$ The Commission brought further infringement proceedings against Hungary, Poland and the Czech Republic, who still refused to relocate, and the Court declared them in breach of their Treaty obligations. ${ }^{38}$ In their defence, the defendant Member States alleged public order reasons for refusing to make any offer of relocation from Italy and Greece, considering that asylum seekers could be potentially 'dangerous'. 39

A new phenomenon, the cleavage between the old Western and the new Central and Eastern European Member States, is emerging in the EU. ${ }^{40}$ This clearly poses another threat to the whole integration project based on trust. To avoid this cleavage, and prevent a possible clash, the Council has moved towards the adoption of special measures allowing for the externalisation of EU border controls: preventing asylum seekers' entry to EU territory by cooperating with third countries in the southern Mediterranean so that they police their coasts to prevent their departure, or apply pushback measures to return irregular entrants. These measures go beyond the provisional measures for emergency situations foreseen in Article 78(3) TFEU and are legally contested. $^{41}$

\subsection{Management of the External Borders and the Securitisation Paradigm}

There are similarities and differences between migration and refugeehood. ${ }^{42}$ One of the basic pillars of migration policy at the EU, relevant to the refugee

37 Slovak Republic and Hungary v Council (n 26). The Court noted that the legality of the relocation decisions could not be called into question on the basis of retrospective assessments of their efficacy. The Council had carried out a detailed examination of the statistical data available at the time and an objective analysis of the effects of the measure on the emergency situation in question, and could not have foreseen the lack of cooperation on the part of certain Member States.

38 Joined Cases C-715/17, C-718/17 and C-719/17 Commission v Hungary, Poland and Czech Republic, ECLI:EU:C:2020:257.

39 A threat to national security, with potential delinquents disguised as asylum seekers (\#135).

40 The cleavage can also be seen in relation to rule of law concerns regarding Poland and Hungary.

${ }_{41}$ Thomas Spijkerboer, 'Bifurcation of people, bifurcation of law: Externalization of migration policy before the EU Court of Justice' (2018) 31(2) Journal of Refugee Studies 216.

42 Migratory dynamics encompass different phenomena, from most protected to least protected: recognised refugees; asylum seekers allowed to stay on humanitarian grounds but refused international protection; rejected asylum seekers; unaccompanied minors; migrants on an expired travel visa; migrants in precarious conditions (irregular). The approach to these phenomena should be coherent, comprehensive and integral. 
question, is control of external borders, which aims at preventing unlawful or irregular entries to the territory of the EU. Frontex surveillance operations, ${ }^{43}$ Europol ${ }^{44}$ and CSDP operations in the Mediterranean (such as Sophia) to dismantle criminal trafficking networks ${ }^{45}$ and the hotspot approach ${ }^{46}$ are examples of the EU's border management policy affecting the rights of asylum seekers and refugees on their way to Europe.

Another tool that the EU has developed to deal with uncontrolled migration, also applied to potential refugees, is readmission agreements. As a response to the 2015 crisis, the EU entered an agreement with Turkey, technically a 'joint declaration', in March 2016, in a special EU summit on asylum held in Malta. ${ }^{47}$ The joint statement is founded on the notion that non-refoulement, the keystone of the Geneva Convention, does not rule out transfer of the asylum seeker into a safe country, in this case Turkey. This opaque instrument ${ }^{48}$ seems to entail a double bilateral arrangement: one between the EU - or EU Member States - and Greece, and another one between Greece and Turkey, according to which each irregular migrant reaching the Greek islands from Turkey and

43 Regulation No. 2016/1624, setting up European Border and Coast Guard, based on Art. 77(2)(b) and (d) and Art. 79(2)(c) TFEU, revamping EU Agency Frontex [2016] OJ L251/1.

44 Through its European Migrant Smuggling Centre (EMSC), established in 2016, and its Joint Operational Team, Mare (2015), Europol coordinates the collective response of law enforcement in Member States to counter organised criminal groups orchestrating the illegal entry of migrants into the EU on a massive scale: www.europol .europa.eu/newsroom/news/europol-launches-european-migrant-smuggling-centre accessed 31 March 2021.

45 Common Security and Defence, EUNAVFOR MED Operation Sophia as part of the EU response to the migration issue, addressing its root causes, including conflict, poverty, climate change and persecution: see www.operationsophia.eu/mission-at-a -glance/ accessed 31 March 2021.

46 EASO, the European Asylum Support Office, Frontex, the European Border and Coast Guard Agency, Europol and Eurojust work on the ground with the authorities of frontline EU Member States facing disproportionate migratory pressures at the EU's external borders to help them fulfil their obligations under EU law and swiftly identify, register and fingerprint incoming migrants: https://ec.europa.eu/home-affairs/e-library/ multimedia/publications/the-hotspot-approach-to-managing-exceptional-migratory -flows_en accessed 31 March 2021.

47 In Joined Cases T-192/16, T-193/16 and T-257/16 NF, NG and NM v European Council, ECLI:EU:C:2018:705, the General Court, by orders, stated that it lacked jurisdiction to hear and determine the actions brought by three asylum seekers against the EU-Turkey statement as it was not an act adopted by any institution of the EU.

48 Details concerning the 'agreement' or press statement are few. The Commission has systematically refused to disclose the documents and Access Info Europe sought access to the documents to uncover the institution's own legal analysis of legality. It brought an action before the General Court, who declared on 7 February 2018 (Case $\mathrm{T}-851 / 16)$ that considerations of public security overrode the public interest. 
not applying for asylum, or failing to be recognised as a refugee, will be individually sent back to Turkey. For every migrant returned, EU Member States undertake to receive one Syrian asylum seeker. In compensation, EU Member States commit to pay Turkey important sums of money and to gradually lift the visa requirement for Turkish citizens travelling to the EU. The opacity of this system is in open contradiction to the spirit of openness proclaimed in Article 1 TEU, requiring decisions to be made according to the rule of law requirements. This 'agreement' has, according to the EU, produced some positive results, but Médécins sans Frontiers considers such claims as 'alternative facts' offered by the EU, and believes that the secondary effects are serious and are being silenced or hidden. ${ }^{49}$ Not only are the effects of the agreement hidden from the public; the content of the agreement itself remains ambiguous. ${ }^{50}$ Externalisation began with Turkey and has extended westwards ever since. ${ }^{51}$ Refugees are becoming a commodity to be transferred between countries, the EU-Turkey 'agreement' being the first example. Some Member States, such as Spain, enter into externalisation agreements bilaterally with African states. ${ }^{52}$ Italy and the EU still cooperate with Libyan coastal guards, ${ }^{53}$ who, trained to control traffickers, deploy interventions against search and rescue operations, block access to rescue boats of NGOs carrying Member States' flags and run inland detention centres controlled by guerrillas who have established a slave trade. ${ }^{54}$ There are many possible explanations for externalisation, but the prevailing one is that tackling the problem through external action, that is, 'at source', is less divisive than facing clashes between Member States over how the division of responsibilities should be conducted in a fair and just manner internally.

49 İlke Toygür and Bianca Benvenuti, 'One year on: an assessment of the EU-Turkey statement on refugees' (Real Instituto Elcano, 21 March 2017), www.realinstitutoelcano .org/wps/portal/rielcano_en/contenido?WCM_GLOBAL_CONTEXT=/elcano/elcano _es/zonas_es/demografia + y+poblacion/ari21-2017-toygur-benvenuti-one-year-on -assessment-eu-turkey-statement-refugees accessed 31 March 2021.

$50 \quad \mathrm{M}$ den Heiker and T Spijkerboer, 'Is the EU-Turkey Refugee and Migration Deal a Treaty?', eulawanalysis.blogspot.se accessed 31 March 2021; see other contributions in the blog, for example Steve Peers'.

51 Malta Declaration at www.consilium.europa.eu/en/press/press-releases/2017/02/ 03/malta-declaration/ accessed 31 March 2021.

52 Blanca Garcés Mascareñas, 'Más externalización del control migratorio', Opinión-CIDOB, 12/2016 www.cidob.org/es/publicaciones/serie_de_publicacion/ opinion/migraciones/mas_externalizacion_del_control_migratorio accessed 31 March 2021.

53 European Agenda on Migration, supra, 'Working in partnership with third countries to tackle migration upstream'.

54 Amnesty International Report, Libya's dark web of collusion, 2017. 


\subsection{A Common European Asylum System Based on Solidarity: A Euphemism}

Internal negotiations to revise the Dublin Regulation with a new system which distributes asylum seekers across the EU based on a distributive key ${ }^{55}$ reveal that there is broad disagreement between the Member States as to what constitutes fair responsibility sharing and what criteria should be followed. ${ }^{56}$ Consensus between destination, transit and arrival Member States on what the principle of solidarity entails is notably missing. ${ }^{57}$ Refugee preferences are not taken into account. Externally, the system focuses on border surveillance primarily through European agencies, a process characterized as agencyfication of EU solidarity, which has intensified after the 2015 refugee crisis. ${ }^{58}$ As discussed above, the externalisation trend is a critical component of the EU's external action on migration and asylum. The economic aspect of such practice is worth taking into account. There is business - money to be made - behind the containment of applicants and the external control of potential applicants by third states, or even the management of visa and asylum applications, processed, for instance, by private companies. Also, besides companies selling security and technological material, smuggler networks are involved in the refugee 'business'. When access to the EU becomes increasingly difficult, smugglers present themselves as the only solution left for those seeking refuge in Europe: irregular entry into the EU, at the risk of being detained and refouled. ${ }^{59}$ With a little luck, European volunteers will come to the rescue in the Mediterranean, and, once on EU territory, their refoulement or inhumane treatment in detention centres may be challenged, not always successfully, through legal proceedings. ${ }^{60}$

There are no alternative, safe routes into the EU for asylum seekers; they are expected to reach a Member State diplomatic delegation in a third country,

55 See earlier Commission Proposal of 4 May 2016, for a Regulation of the European Parliament and of the Council establishing the criteria and mechanisms for determining the Member State responsible for examining an application for international protection lodged in one of the Member States by a third-country national or a stateless person (recast), $\operatorname{COM}(2016) 270$ final, 2016/0133 (COD).

56 Bejan (n 31).

57 Annik Pijnenburg, 'Containment instead of refoulement: Shifting state responsibility in the age of cooperative migration control?' (2020) 20(2) Human Rights Law Review 306.

58 David Fernandez Rojo, EU Migration Agencies: The Operation and Cooperation of FRONTEX, EASO and EUROPOL (Edward Elgar Publishing 2021).

59 Bauman (n 12) ch. 3.

60 Grand Chamber judgment of the CJEU of 14 May 2020 in joined cases C-924/19 PPU and C-925/19 PPU, concerning Röszke transit zone in Hungary. 
hand in their application and wait for weeks, months or years to receive, almost certainly, a rejection. Although the "Visa Code' ${ }^{61}$ is also part of the system, each Member State applies its own norms and standards for awarding the visa and the status of refugee, and the results are different from one Member State to another. A step forward was Advocate General Mengozzi's Opinion in case $X$ et $X \mathrm{v}$ Etat belge, highlighting the obligation of Member States to award humanitarian visas in cases where there is a serious risk of breach of Article 4 of the Charter, regardless of any connection with the state. Sadly, the Court of Justice, ${ }^{62}$ and also the European Court of Human Rights, lost the opportunity to apply a more principled interpretation of European law in line with international human rights standards.

In recognition, perhaps, of the shortcomings of this euphemistic Common European Asylum System, the Commission has proposed the New Pact on Immigration and Asylum, presented as 'a new balance between responsibility and solidarity'. ${ }^{63}$ The New Pact intends to review and update the regulatory framework, bringing together all aspects of asylum and migration policy. ${ }^{64}$ This new approach not only persists in conflating migration and asylum, but also channels European-level solidarity into relocation or return sponsorship. It remains to be seen how all the regulatory reforms will be finally agreed by the EU legislative institutions. Nevertheless, the 2015 European Agenda on Migration claims that 'Europe should continue to be a safe haven for those fleeing persecution as well as an attractive destination for the talent and

${ }^{61}$ Regulation (EU) No 610/2013 of the European Parliament and of the Council of 26 June 2013 OJ 2013 L 182, p. 1.

62 C-638/16 PPU, $X$ et $X$ c Etat belge [2017] ECR nyr. The question was whether a visa should be granted, on human rights' grounds, to the Syrian applicants to enter Belgium in order to then apply for protection. The Court declared the case inadmissible, being outside the scope of the Visa Code, and on 5 May 2020 the ECHR (Grand Chamber) declared the case, registred as M., N. et autres $c$. Belgique, inadmissible as the Convention does not apply to individuals who are not under the jurisdiction of Contracting Parties.

63 Communication from the Commission to the European Parliament, the Council, the European Economic and Social Committee and the Committee of the Regions, A European Agenda on Migration, COM (2015) 240 final, and for the New Pact, Communication COM (2020) 609 final, 2020-09-23, and Commission info-publicity website https://ec.europa.eu/info/strategy/priorities-2019-2024/promoting-our -european-way-life/new-pact-migration-and-asylum_en, visit 2021/02/25 accessed 31 March 2021.

64 The Asylum Procedures Regulation, the Qualification Directive, the Reception Conditions Directive, the EU Asylum Agency Regulation, the Union Resettlement Framework and the Return Directive. The Commission is to withdraw its 2016 proposal amending the Dublin Regulation, which is to be replaced by a new, broader instrument, the Asylum and Migration Management Regulation. 
entrepreneurship of students, researchers and workers'. Under the Geneva Convention non-refoulement is a fundamental principle of international law; persons fulfilling the refugee definition criteria are protected, and should not be forcefully returned to a country where their life and liberty may be in danger. As regards migration, no matter how much the EU would like to attract talent, the decision to grant visas and residence lies entirely with the Member States and the EU lacks a true common policy on migration (New Pact VII). If at all, it contemplates migration as a labour adjustment of the single market, leaving a broad margin of discretion to national governments. An agenda for social integration of migrants is also lacking at EU level (New Pact VIII).

The analysis so far reveals that the link between the weak external action of the EU, its security and defence policies and its immigration and refugee agendas is systemic. So far, the EU and the Member States have relied on patchy and provisional solutions, which enhance the securitization paradigm at the expense of human rights.

\section{CONCLUSION}

Why do the EU and relevant legislation allow the situation described above? And who is the EU, in this case? EU institutions, Member States, political parties, peoples, NGOs, mass media, citizens - all are involved in the responses. Some of the Member States' political parties and officials have engaged in populist discourses, converting those who flee from danger in their countries into potential dangerous individuals who enter our territory illegally and take our jobs. The EU institutions sometimes fall into these discourses, praising Italy or Greece for having considerably reduced the number of entrants seeking asylum and for having increased the capacity of detention centres and refugee hotspots.

The value of solidarity proclaimed by the EU Treaties is translated into policies decided by the Council, which meet resistance from the Member States. Temporary quotas are decided upon, yet no serious account is taken of the efforts that Mediterranean Member States, especially Spain, Greece and Italy, are making as regards coastal control and rescue operations. Member States have failed to share the responsibilities for refugees in spite of clear rulings from the Court of Justice, thus failing to observe the solidarity clause. On the other hand, securitised responses, such as externalisation of border control, receive full support. The EU and its Member States, with some exceptions, are failing in their human rights duties towards asylum seekers. 
Solidarity with refugees as well as with countries of origin and transit is missing. ${ }^{65}$ The series of crises experienced - an influx of asylum seekers and migrants, Brexit, the near collapse of the financial system, austerity measures, youth unemployment, public deficit and public debt restructuring measures, the Covid-19 pandemic - drives the EU into an existential dilemma: is Europe the same self-proclaimed power based on values, human dignity, fundamental rights and solidarity, or has it morphed into something different?

Solidarity between Member States, and towards third countries, has failed, as security overrides protection. But there is solidarity by citizens, a type of expressive horizontal solidarity between people (persons) that should not be underestimated. In this climate of risk and uncertainty, it is thanks to volunteers and humanitarian NGOs, and to jurists, that European values enshrined in the TEU and the Charter are being preserved. The Charter and the European Convention of Human Rights (ECHR) should be a constant check on state policies and practice, as a benchmark to identify cases of injustice. ${ }^{66}$ However, it is hard to discern a clear line to prioritise refugee rights over the internal market, due to lack of coherence in the case-law of the European Courts. ${ }^{67}$

The need for cheap labour, or for qualified labour, or to address a demographic deficit and ageing populations has led to the treatment of persons as exchange value, and of refugees as risk. But persons are not commodities and de-commodification is essential - not only for workers, for the precariat, for women or for refugees and migrants, but for our solidarity constitution itself. It is relatively easy to offer alternative frames: simply by reading what we, as Europeans, have committed to uphold in the Lisbon Treaties and in the Charter or in the ECHR, we can point to the need to protect and respect people. Pope Francis' 'dream of a Europe where being a migrant is not a crime, but a summons to a greater commitment on behalf of the dignity of every human being' requires us 'to promote an integration that finds in solidarity a way of acting, a means of making history'. Solidarity should be 'understood as a means of creating opportunities for all the inhabitants of our cities - and of so many other cities - to live with dignity. Time is teaching us that it is not

\footnotetext{
65 Bauman (n 12).

66 Amartya Sen, The Idea of Justice (Allen Lane 2009) argues we do not need to know what perfect justice is as long as we can identify injustices.

67 Some judgments give cause for hope. In Ministerio Fiscal C-36/20 PPU, the Court ruled that examining magistrates are required to inform the applicant as to the specific procedures for lodging an application for protection, and that not finding accommodation in a humanitarian reception centre cannot justify keeping in detention an applicant for international protection. This is well in line with the FMS judgment (C-924/19 PPU and C-925/19 PPU) that the placing of all applicants for international protection in one of the transit zones during the examination of their applications constitutes 'detention'.
} 
enough simply to settle individuals geographically.' ${ }^{68}$ The challenge is that of living together, and living up to the solidarity constitution. ${ }^{69}$

68 Discourse of acceptance of the Charlemagne prize 6 May 2016. See also AG Sharpston's Opinion in jc, Commission v Poland, Hungary and Czech Republic, fn 39. ${ }_{69}$ Tuori (n 1). 